\title{
Hydrogen Sulfide Inhalation Improves Neurological Outcome via NF-kB-Mediated Inflammatory Pathway in a Rat Model of Cardiac Arrest and Resuscitation
}

\author{
Xia Wei ${ }^{a}$ Bing Zhang ${ }^{b}$ Yu Zhang ${ }^{b}$ Hangbing Li ${ }^{b}$ Long Cheng ${ }^{b}$ Xiajie Zhao ${ }^{b}$ \\ Jinling Yin ${ }^{b}$ Guonian Wang ${ }^{a}$ \\ aDepartment of Anesthesiology, Cancer Hospital Affiliated to Harbin Medical University, ${ }^{b}$ Department \\ of Anesthesiology, Second Affiliated Hospital of Harbin Medical University, Harbin, China
}

\section{Key Words}

Cardiac arrest $\bullet$ Inflammation $\bullet$ Brain recovery $\bullet$ Hydrogen sulfide $\bullet$ NF-KB

\begin{abstract}
Background/Aims: The effects of $\mathrm{H}_{2} \mathrm{~S}$ on cerebral inflammatory reaction after cardiac arrest (CA) and cardiopulmonary resuscitation (CPR) remain poorly understood. In this study, we investigated the effects of exogenous $40 \mathrm{ppm}$ and $80 \mathrm{ppm} \mathrm{H}_{2} \mathrm{~S}$ gas on inflammatory reaction and neurological outcome after CA/CPR. Methods: CA was induced by ventricular fibrillation and followed by CPR. Forty or $80 \mathrm{ppm} \mathrm{H}_{2} \mathrm{~S}$ was inhaled for $1 \mathrm{~h}$ immediately following CPR. The levels of IL-1 $\beta$, IL- 6 and TNF- $\alpha$, the myeloperoxidase (MPO) activity, the expression of iNOS and ICAM-1, and the phosphorylation and translocation of NF-kB were evaluated at $24 \mathrm{~h}$ after CA/ CPR. The tape removal test, survival rate and hippocampal neuronal counts were investigated at $14 \mathrm{~d}$ after CA/CPR. Results: CA/CPR induced significant increases in IL-1 $\beta$, IL-6, TNF- $\alpha$ and MPO activity. The phosphorylation and translocation of NF-KB, and the expression of iNOS

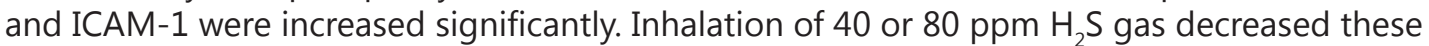
inflammatory cytokines. Furthermore, 40 or $80 \mathrm{ppm} \mathrm{H}_{2} \mathrm{~S}$ inhibited the activation of NF- $\mathrm{kB}$ and the downstream proinflammatory mediators iNOS and ICAM-1. $\mathrm{H}_{2} \mathrm{~S}$ inhalation also improved neurological function, 14-d survival rate, and reduced hippocampal neuronal loss. Conclusion: These results indicated that inhalation of $\mathrm{H}_{2} \mathrm{~S}$ protected against brain injury after CA/CPR. The mechanisms underlying protective effects of $\mathrm{H}_{2} \mathrm{~S}$ were associated with the inhibition of $\mathrm{CA} /$ CPR-induced inflammation reactions by reducing IL- $1 \beta$, IL- 6 and TNF- $\alpha$, and concomitantly inhibiting the activation and infiltration of neutrophils. The beneficial effects of $\mathrm{H}_{2} \mathrm{~S}$ might be mediated by downregulation of NF-KB and the downstream proinflammatory signaling pathway.

Copyright (C) 2015 S. Karger AG, Basel
\end{abstract}

Prof. Guonian Wang

KARGER 125
Department of Anesthesiology, Cancer Hospital Affiliated to Harbin Medical University, 150 Haping Road, 150081 Harbin (China)

Tel./Fax+86-451-86605028, E-Mail wangguonian2015@126.com 


\section{Cellular Physiology Cell Physiol Biochem 2015;36:1527-1538

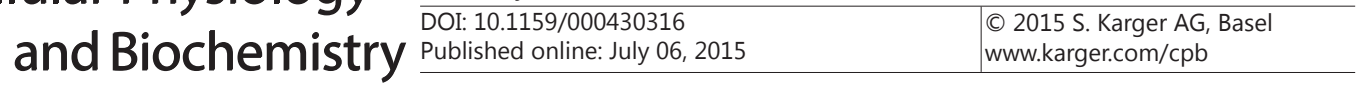 \\ Wei et al.: $\mathrm{H}_{2} \mathrm{~S}$ Improves Neurological Outcome via NF-KB-Mediated Inflammation after CPR}

\section{Introduction}

Sudden cardiac arrest (CA) is a serious public health problem affecting more than 450,000 individuals annually [1]. Among these patients, only 10 to $40 \%$ survive. Worse, more than half of the survivors have various permanent neurological consequences, with only 5 to $17 \%$ of CA and cardiopulmonary resuscitation (CA/CPR) patients discharged without a serious neurological problem [1-3]. Apart from induced hypothermia, no other specific treatment is available to reduce neuronal death and improve functional outcome after CA/CPR till now.

Previous studies had shown that the inflammatory response were a major contributor to exacerbate brain injury following cerebral ischemia [4]. It has been reported that cerebral ischemia leads to significantly elevated levels of pro-inflammatory mediators such as tumor necrosis factor (TNF)- $\alpha$, interleukin (IL)- $1 \beta$ and IL-6, which further induce the recruitment and activation of various types of leukocytes including the neutrophils $[5,6]$. Those mediators accumulate in the capillaries and impair cerebral blood flow, extravasate into the brain parenchyma, produce excessive reactive oxygen species, or induce matrix metalloproteinase- 9 and exert deleterious effects on the progression of tissue damage. Therefore, inhibition of the inflammatory response may provide a potential treatment target for neuroprotection in brain ischemia.

Additional data suggest that hydrogen sulfide $\left(\mathrm{H}_{2} \mathrm{~S}\right)$ plays important roles in cardiovascular, neuronal, renal, respiratory, gastrointestinal, hepatic and endocrine systems $[7,8]$. Recent studies have demonstrated that $\mathrm{H}_{2} \mathrm{~S}$ donor $\left(\mathrm{Na}_{2} \mathrm{~S}\right.$ or NaHS) have protective effects after brain ischemia and reperfusion including CA/CPR $[9,10]$. However, there are few data about the effects of exogenous $\mathrm{H}_{2} \mathrm{~S}$ gas on CA/CPR. In our previous study, we revealed that inhalation of $80 \mathrm{ppm} \mathrm{H}_{2} \mathrm{~S}$ gas improved brain metabolism and reduced neurohistopathological damage after CA/CPR in rabbits [11]. But more direct evidence for the neuroprotective effect of $\mathrm{H}_{2} \mathrm{~S}$ gas is still lacking. In recent studies, the anti-inflammatory actions of $\mathrm{H}_{2} \mathrm{~S}$ in different models were detected [12-16]. Therefore, the present study was aimed to investigate the effect of exogenous $\mathrm{H}_{2} \mathrm{~S}$ gas on neuroinflammation in the early reperfusion period after CA/CPR. Furthermore, the effects of $\mathrm{H}_{2} \mathrm{~S}$ on neurological outcome and neuronal survival were also investigated.

\section{Materials and Methods}

This study was approved by the Institutional Animal Care and Use Committee of Harbin Medical University in Harbin, Heilongjiang, China, and followed national guidelines (Guidelines on Administration of Laboratory Animals in China \& Guidelines on the Humane Treatment of Laboratory Animals in China) for the treatment of animals.

\section{Subjects and surgical procedures}

We tested male Sprague-Dawley rats weighing 280-300 g in this study. Animals had access to food and water ad libitum until the morning of the experiment. Animals were anesthetized with $1-2 \%$ halothane and $30 \%$ oxygen. Ventilation was controlled with a small animal ventilator (Inspira ASV, Harvard Apparatus Inc., MA, USA) to maintain arterial $\mathrm{pH}$ at 7.35-7.45, $\mathrm{PaCO}_{2}$ at 35-45 mmHg, and $\mathrm{PaO}_{2}$ over $90 \mathrm{mmHg}$. Pericranial temperature was monitored using a thermistor probes (BIOPAC Systems Inc., CA, USA) percutaneously placed adjacent to the skull. The pericranial temperature was maintained at $37 \pm 0.5^{\circ} \mathrm{C}$ throughout the experiments. A standard lead II ECG was recorded continuously using subdermal needle-type electrodes placed in the limbs. The right femoral artery and vein were cannulated with PE-50 catheters for continuous monitoring of blood pressure, measurement of blood gases, infusion of fluid, and drug administration. All of the physiology data were monitored and recorded using the BIOPAC MP150 physiometer (BIOPAC Systems Inc.). The number of animals and the flow diagram of the experimental groups were shown in Figure 1.

CA protocol

We induced ventricular fibrillation using an esophageal electrode (5F, Bard Peripheral Vascular Inc., Tempe, AZ) by a 1-min impulse of $12 \mathrm{~V}$ at $50 \mathrm{~Hz}$ alternating current. If spontaneous defibrillation occurred, 
Fig. 1. Flow diagram of the experimental groups. ROSC $=$ return of spontaneous circulation; MPO = Myeloperoxidase; Sham = sham group, $\mathrm{CA}=$ cardiac arrest group; $\mathrm{H}_{2} \mathrm{~S} \quad 40=\mathrm{H}_{2} \mathrm{~S} 40$ group; $\mathrm{H}_{2} \mathrm{~S} \quad 80=$ $\mathrm{H}_{2} \mathrm{~S} 80$ group.

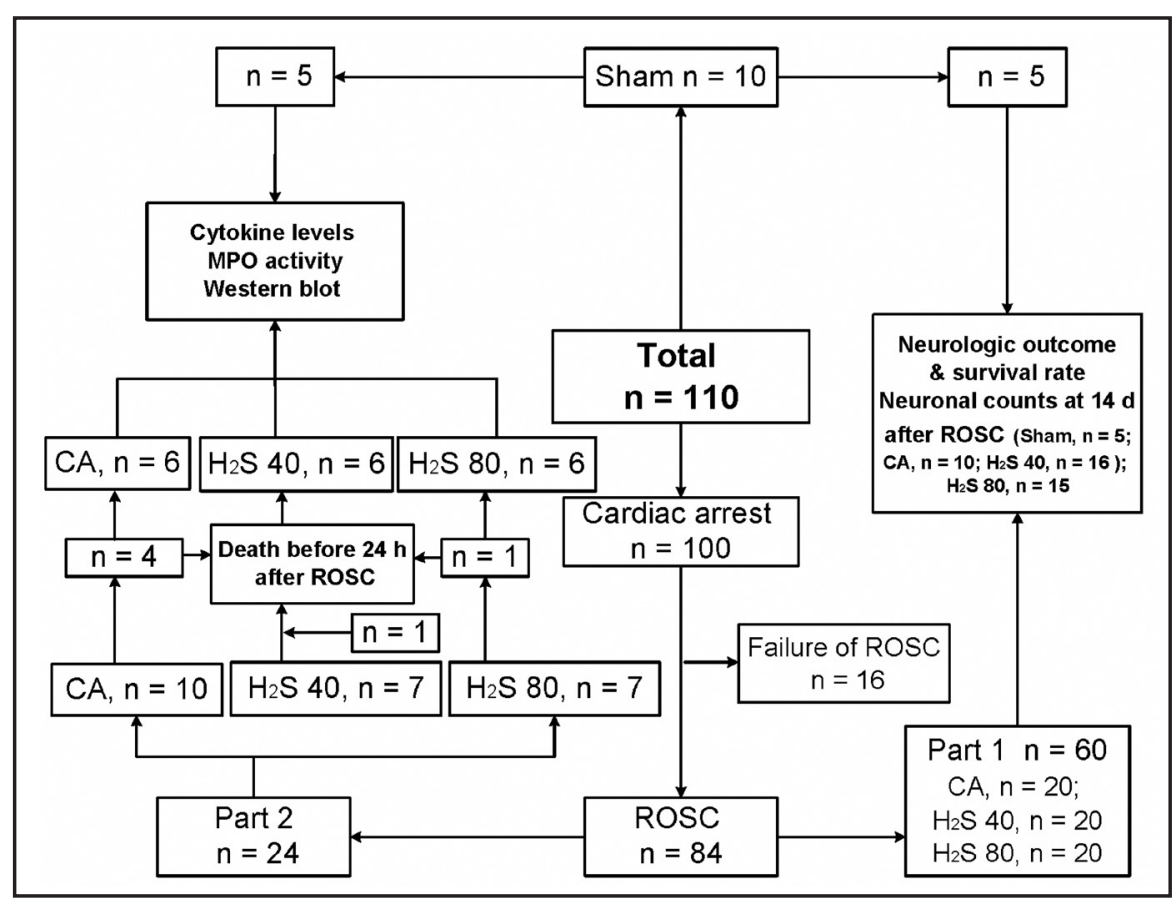

we delivered additional $20 \mathrm{~s}$ impulses [17]. CA was confirmed by an abrupt decrease in MAP to less than 15 mmHg; when that occurred, ventilation was stopped.

After 6 min of CA, CPR was implemented by reconnecting the ventilator with $\mathrm{FiO}_{2}=1.0$, administering epinephrine $(0.02 \mathrm{mg} / \mathrm{kg})$ and sodium bicarbonate $(1 \mathrm{mEq} / \mathrm{kg})$, and applying sternal compressions at a rate of 200 per min. After 2 min of CPR, we applied external defibrillation (biphasic, 2 J; Zoll M-series Defibrillator, ZOLL Medical U.K. Ltd, Cheshire, England). The cycle of 1 min of chest compression followed by defibrillation was repeated, if necessary, until the return of spontaneous circulation (ROSC) or the elapse of more than $10 \mathrm{~min}$. Successful ROSC was defined as an initial return of a sinus ECG rhythm with an obvious arterial wave form and MAP of $50 \mathrm{mmHg}$ or greater lasting at least $5 \mathrm{~min}$. Resuscitated rats were randomly assigned into the CA group $\left(\mathrm{FiO}_{2}=0.5\right.$, without $\mathrm{H}_{2} \mathrm{~S}$ gas $)$, the $\mathrm{H}_{2} \mathrm{~S} 40$ group, and the $\mathrm{H}_{2} \mathrm{~S} 80$ group $\left(\mathrm{FiO}_{2}=0.5\right.$, with $40 \mathrm{ppm}$ or $80 \mathrm{ppm} \mathrm{H}_{2} \mathrm{~S}$ gas for $1 \mathrm{~h}$ mechanically ventilation). We monitored blood gas analyses at 15 and $30 \mathrm{~min}$ after ROSC, and appropriate ventilator adjustments were made, if necessary. After ROSC had been established for $1 \mathrm{~h}$, the vascular catheters were removed. Surgical wounds were sutured and infiltrated with $0.25 \%$ bupivacaine (total $0.5 \mathrm{mg}$ ). Rats were then weaned from the ventilator and extubated. To avoid hypoxic episodes, rats were placed in a chamber enriched with $50 \%$ oxygen for another $1 \mathrm{~h}$. The oxygen

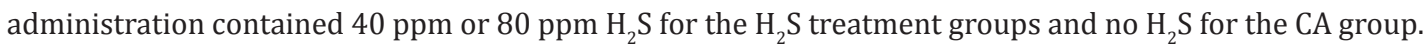
After that rats were returned to their cages with easily accessible food and water. Shams underwent all same procedures as were administered to the CA and the $\mathrm{H}_{2} \mathrm{~S}$ groups, except that the shams received no ventricular fibrillation or CPR.

\section{Assessment of neurologic outcome and survival rate}

We familiarized all animals to the neurologic test for 3 consecutive days and evaluated them before the experiment to ensure normal neurologic function. We determined neurologic outcomes at 1, 3, and 14 $\mathrm{d}$ after ROSC and 14-d survival rates. We evaluated sensorimotor integration using a modified tape removal test (TRT) [18]. We recorded the time to remove both adhesive tapes, with all times greater than $180 \mathrm{~s}$ recorded as $180 \mathrm{~s}$. The same investigator, who was blinded to treatment, carried out all evaluations.

\section{Neuronal counts}

For hippocampal neuronal counts, the rats that survived for $14 \mathrm{~d}$ and those in the sham group were investigated. Immediately after euthanization, rats were perfused through the heart with phosphatebuffered saline and $4 \%$ paraformaldehyde. We examined $5 \mu \mathrm{m}$ coronal serial sections of the hippocampus of fixed brains embedded in paraffin. Sections corresponded to bregma $-3.3 \mathrm{~cm}$, according to the atlas of 


\section{Cellular Physiology Cell Physiol Biochem 2015;36:1527-1538 \begin{tabular}{l|l} 
and Biochemistry $10.1159 / 000430316$ & $\begin{array}{l}\text { O 2015 S. Karger AG, Basel } \\
\text { www.karger.com/cpb }\end{array}$ \\
\hline
\end{tabular}

Paxinos and Watson [19]. Neurons were judged to be viable, if they showed a distinct nucleus and nucleolus; non-viable ischemic neurons exhibited nuclear pyknosis, karyorrhexis, and vacuolization. One observer, who was blinded to the experimental protocol, counted the numbers of viable pyramidal neurons per highpower field $(\times 400)$.

Cerebral cytokine levels and MPO activity in brain tissue

At $24 \mathrm{~h}$ after ROSC, animals were deeply anesthetized by halothane. Brain tissues were rapidly dissected out and frozen immediately at $-80^{\circ} \mathrm{C}$. Each brain tissue sample was homogenized in phosphate-buffered saline and centrifuged at $10,000 \mathrm{~g}$ at $4^{\circ} \mathrm{C}$ for $10 \mathrm{~min}$. The supernatants from brain tissues were collected and, using the commercially available ELISA kits (Abcam, Cambridge, MA), we measured the concentrations of IL-1 $\beta$, IL-6, TNF- $\alpha$, and MPO activity. We prepared reagents, samples, and working standards according to the manufacturer's instructions at room temperature. Each sample was run in duplicate and evaluated using a microplate reader (BioTek Instruments Inc, Winooski, VT), as recommended by the manufacturer. One unit of MPO activity was defined as the amount that degraded $1 \mu$ mol hydrogen peroxide per min at $25^{\circ} \mathrm{C}$. The activity was expressed as units/g tissue.

Western blot analysis for $N F-\kappa B$, iNOS, and ICAM-1

Protein homogenates of brain samples were prepared by rapid homogenization in Tissue Extraction Reagent II (Invitrogen Corporation, Carlsbad, CA), according to the manufacturer's instructions. The supernatant was used for western blot analyses of inducible nitric oxide (iNOS) and intercellular adhesion molecule-1 (ICAM-1) expressions. In the case of the NF- $\mathrm{B}$ activation, including phosphorylation and translocation to the nucleus, analyses were carried out on nuclear extracts. Nuclear and cytoplasmic proteins were separated according to the protocol described in Thermo Scientific NE-PER Nuclear and Cytoplasmic Extraction kit (Pierce Biotechnology, Rockford, IL). Protein concentrations were measured using a BCA Protein Assay Kit (Beyotime Biotech, China). Proteins were separated by $10 \%$ SDS polyacrylamide gels, separated by gel electrophoresis (Mini Protean III, Biorad, NZ), and transferred onto a $0.45 \mu \mathrm{m}$ polyvinylidene difluoride membrane (Millipore Corporation, Bedford, MA). The membranes were blocked $5 \%$ skim milk powder in TBST and then incubated overnight at $4^{\circ} \mathrm{C}$ with anti-ICAM-1 (1:1000; BIOS, China),

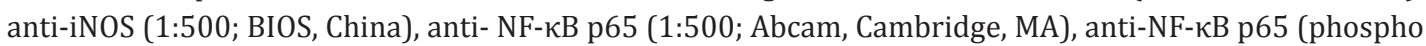
S536) (1:500; Abcam, Cambridge, MA), anti-actin (1:2000; Zhongshan Golden Bridge Biotechnology, China), and anti-Histone H2A (1:500, Santa Cruz, CA). After washing with TBST, the membranes were incubated with horseradish peroxidase-conjugated anti-mouse or anti-rabbit antibodies (1:3000, Zhongshan Golden Bridge Biotechnology, China). Bands were detected using the enhanced chemiluminescence detection system (Beyotime Biotech, China), and protein band densities were digitally quantified and normalized to $\beta$-actin or Histone H2A using Image J software (NIH, USA).

\section{Statistical Analysis}

TRT scores were expressed as median and interquartile range (25th to 75th percentiles) and analyzed by the Kruskal-Wallis test, followed by post-hoc Mann-Whitney U tests, when the overall Kruskal-Wallis result was significant. Other data are presented as the mean \pm SD and analyzed by one-way ANOVA, with Bonferroni correction for post hoc comparisons between multiple experimental groups. Kaplan-Meier survival curves were compared using the log-rank test. We considered probability values of $P<0.05$ to be significant. Statistical analysis was performed using SPSS ${ }^{\circledR}$ software (SPSS Inc., Chicago, IL).

\section{Results}

Overall Survival Rate and TRT after ROSC

All 5 of the rats in the sham group survived through the $14 \mathrm{~d}$ observation period. Of the 20 rats in the CA group, 10 died and the remaining 10 survived through $14 \mathrm{~d}$. Four rats died in the $\mathrm{H}_{2} \mathrm{~S} 40$ group and 5 rats died in the $\mathrm{H}_{2} \mathrm{~S} 80$ group. Finally, 10 of 20 rats (50\%) in the CA group, 16 of 20 rats ( $80 \%$ ) in the $\mathrm{H}_{2} \mathrm{~S} 40$ group, and 15 of 20 rats $(75 \%)$ in the $\mathrm{H}_{2} \mathrm{~S} 80$ group survived until day 14 . As depicted in Figure 2, there was a significant difference in the 14-d survival rate between the CA group and $\mathrm{H}_{2} \mathrm{~S} 40$ or $\mathrm{H}_{2} \mathrm{~S} 80$ group (both $P<0.05$ ). 


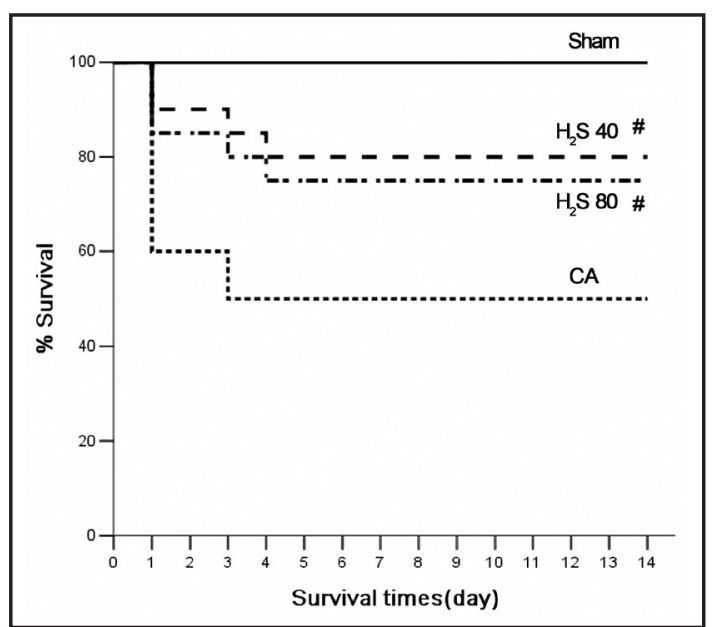

Fig. 2. Kaplan-Meier plot of cumulative survival 14 days after cardiac arrest and resuscitation in Sham $(\mathrm{n}=5), \mathrm{CA}(\mathrm{n}=20), \mathrm{H}_{2} \mathrm{~S} 40(\mathrm{n}=20)$ and $\mathrm{H}_{2} \mathrm{~S} 80(\mathrm{n}=$ 20) groups. Sham = Sham group; $C A=$ cardiac arrest group; $\mathrm{H}_{2} \mathrm{~S} 40=\mathrm{H}_{2} \mathrm{~S} 40$ group; $\mathrm{H}_{2} \mathrm{~S} 80=\mathrm{H}_{2} \mathrm{~S} 80$ group. \# $P<0.05$ vs. CA group.

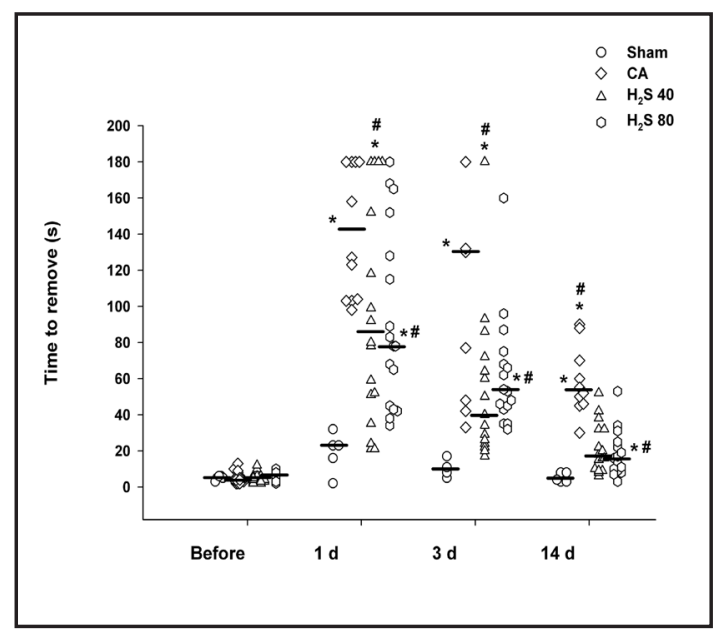

Fig. 3. Tape removal test (TRT) at day 1 , day 3 , and day 14 after cardiac arrest and resuscitation. Open circles indicate values for individual animals. Horizontal bars indicate median values. Sham $=$ Sham group; $\mathrm{CA}=$ cardiac arrest group; $\mathrm{H}_{2} \mathrm{~S} 40=\mathrm{H}_{2} \mathrm{~S} 40$ group; $\mathrm{H}_{2} \mathrm{~S} 80=\mathrm{H}_{2} \mathrm{~S} 80$ group. ${ }^{*} P<0.05$ vs. Sham group, ${ }^{\#} P<0.05$ vs. CA group.

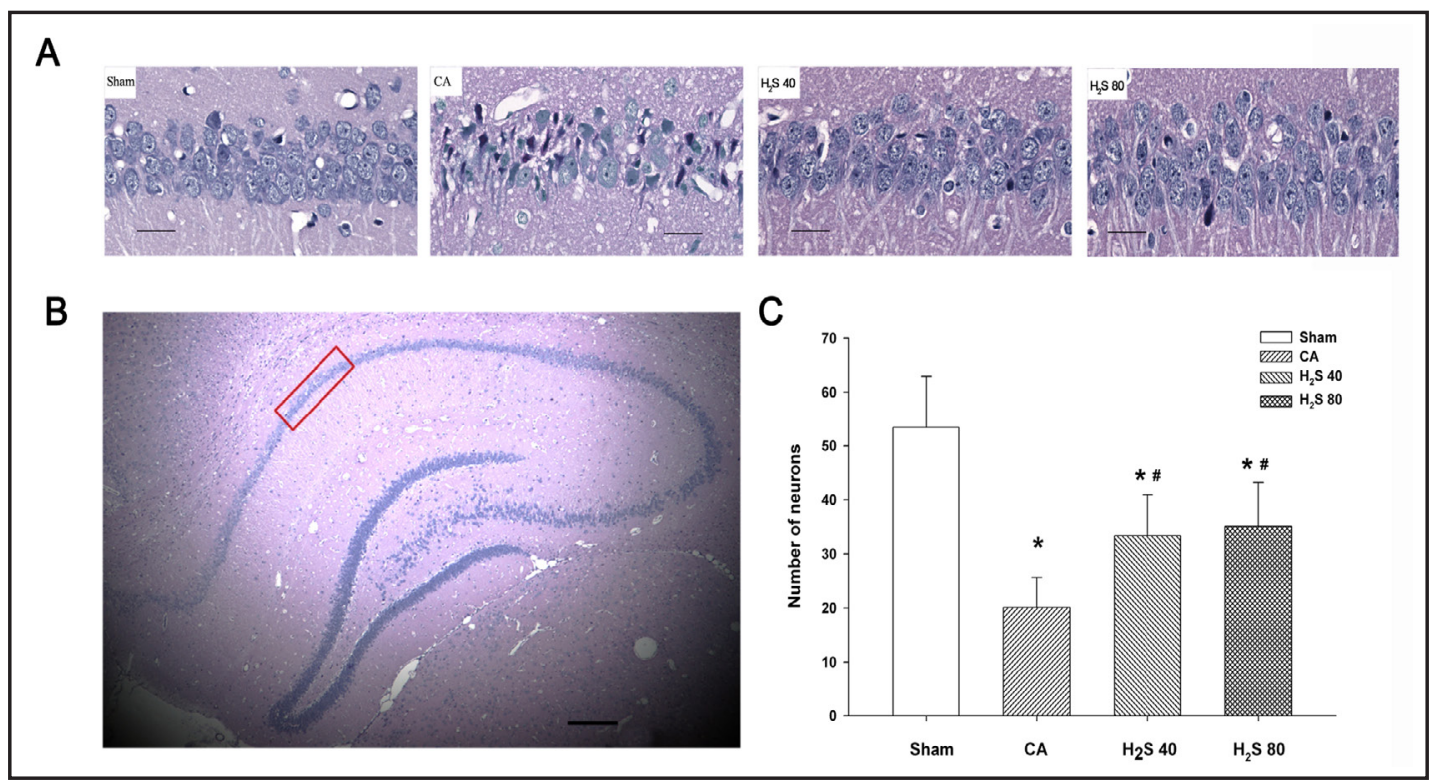

Fig. 4. The histological images of neuron and viable neuronal counts in the hippocampus CA1 region in Sham, CA, $\mathrm{H}_{2} \mathrm{~S} 40$ and $\mathrm{H}_{2} \mathrm{~S} 80$ groups at $14 \mathrm{~d}$ after cardiac arrest and resuscitation. (A) Representative histological images of neuron in the hippocampus CA1 region. (B) The hippocampus CA1 region. (C) The number of neurons in different groups. Sham = Sham group; $\mathrm{CA}=$ cardiac arrest group; $\mathrm{H}_{2} \mathrm{~S} 40=\mathrm{H}_{2} \mathrm{~S} 40$ group; $\mathrm{H}_{2} \mathrm{~S}$ $80=\mathrm{H}_{2} \mathrm{~S} 80$ group. ${ }^{*} P<0.05$ vs. Sham group, ${ }^{\#} P<0.05$ vs. CA group.

Before the experiment, all animals removed the TRT adhesive tapes rapidly and there were no differences between groups. After ROSC, dramatic increases in TRT latencies showed a severe neurologic deficit in all resuscitated animals. The times needed in TRT trials increased from $4 \mathrm{~s}$ (3-6 s) before CA to $142 \mathrm{~s}$ (103-180 s) on day 1 and then fell to $130 \mathrm{~s}$ (47-180 s) on day 3 and 54 s (46-75 s) on day 14 in the CA group. As can be seen in Figure 
Fig. 5. Cytokines levels (A) and MPO activities (B) in brain tissue at $24 \mathrm{~h}$ after resuscitation in Sham, CA, $\mathrm{H}_{2} \mathrm{~S}$ 40 and $\mathrm{H}_{2} \mathrm{~S} 80$ groups. Sham = sham group; $\mathrm{CA}=$ cardiac arrest group; $\mathrm{H}_{2} \mathrm{~S}$ $40=\mathrm{H}_{2} \mathrm{~S} 40$ group; $\mathrm{H}_{2} \mathrm{~S} 80=\mathrm{H}_{2} \mathrm{~S} 80$ group. * $P<0.05$ vs. Sham group, ${ }^{*} P<$ 0.05 vs. CA group.

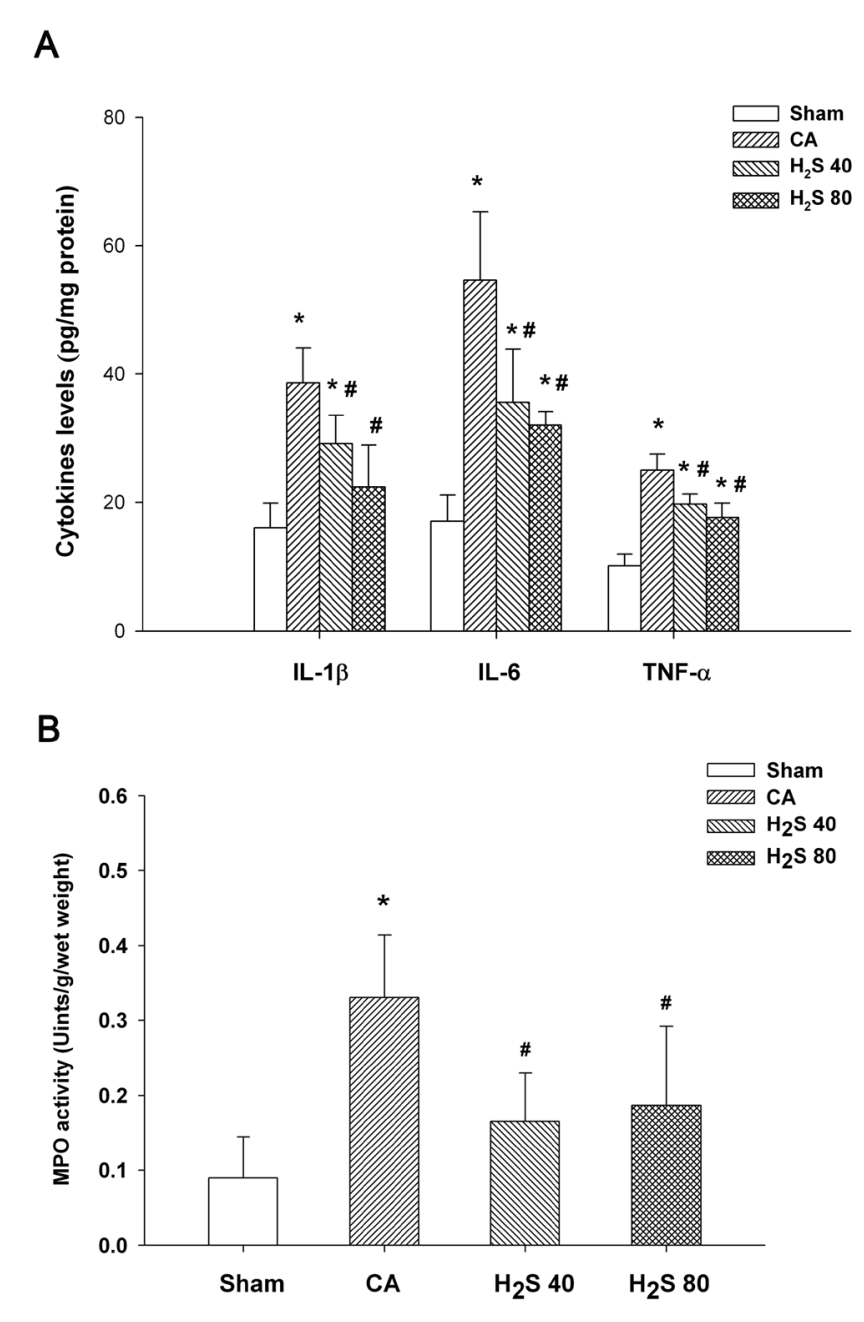

3 , compared with the CA group, the $\mathrm{H}_{2} \mathrm{~S} 40$ group differed significantly from day 1 (86 s (47$180 \mathrm{~s}), P<0.05)$ to day $3(40 \mathrm{~s}(25-79 \mathrm{~s}), P<0.05)$ and day $14(17 \mathrm{~s}(9-32 \mathrm{~s}), P<0.05)$. The similar trend was also observed in $\mathrm{H}_{2} \mathrm{~S} 80$ group from day 1 (78 s (44-140 s), $\left.P<0.05\right)$ to day 3 (54 s (44-73 s), $P<0.05)$ and day 14 (16 s (9-25 s), $P<0.05)$ when compared with CA group. No significant differences were observed between the $\mathrm{H}_{2} \mathrm{~S} 40$ group and the $\mathrm{H}_{2} \mathrm{~S} 80$ group from day 1 to day 14 (Fig. 3).

\section{Neuronal Counts}

As shown in Figure 4, hematoxylin-eosin staining showed a massive reduction of vital neurons in all resuscitated animals. Nuclear pyknosis, karyorrhexis, and vacuolization were also observed in the hippocampus CA1 region in the CA group. However, the neuronal density and cell morphology were relatively well preserved in the $\mathrm{H}_{2} \mathrm{~S} 40$ and $\mathrm{H}_{2} \mathrm{~S}$ 80group. For comparison, the number of viable neurons in the CA group $(20 \pm 6)$ was significantly less than in the sham group $(53 \pm 10, P<0.05)$. A larger number of viable neurons was observed in the $\mathrm{H}_{2} \mathrm{~S} 40$ group $(33 \pm 8, P<0.05)$ and $\mathrm{H}_{2} \mathrm{~S} 80$ group $(35 \pm 8, P<0.05)$ than in the CA group, but both still less than that in the sham group (both $P<0.05$ ).

Effects of $\mathrm{H}_{2}$ S on $I L-1 \beta, I L-6, T N F-\alpha$, and MPO activity in brain tissue

At $24 \mathrm{~h}$ after ROSC, the brains of CA rats showed significantly higher levels of IL-1 $\beta$ than that from sham group rats $(38.62 \pm 5.43 \mathrm{pg} / \mathrm{mg}$ vs. $15.99 \pm 3.86 \mathrm{pg} / \mathrm{mg}, P<0.05)$. Compared 
Fig. 6. Effects of $\mathrm{H}_{2} \mathrm{~S}$ on NF- $\kappa \mathrm{B}$ phosphorylation (A) and translocation (B) in Sham, CA, $\mathrm{H}_{2} \mathrm{~S}$ 40 and $\mathrm{H}_{2} \mathrm{~S} 80$ groups after CA/ CPR. Representative immunoblots for P65, phospho-P65 (p-P65), $\beta$-actin and Histone H2A are shown above the bars. Sham = sham group; $\mathrm{CA}=$ cardi ac arrest group; $\mathrm{H}_{2} \mathrm{~S} 40=\mathrm{H}_{2} \mathrm{~S} 40$ group; $\mathrm{H}_{2} \mathrm{~S} 80=\mathrm{H}_{2} \mathrm{~S} 80$ group. * $P<0.05$ vs. Sham group, ${ }^{\#} P<$ 0.05 vs. CA group.

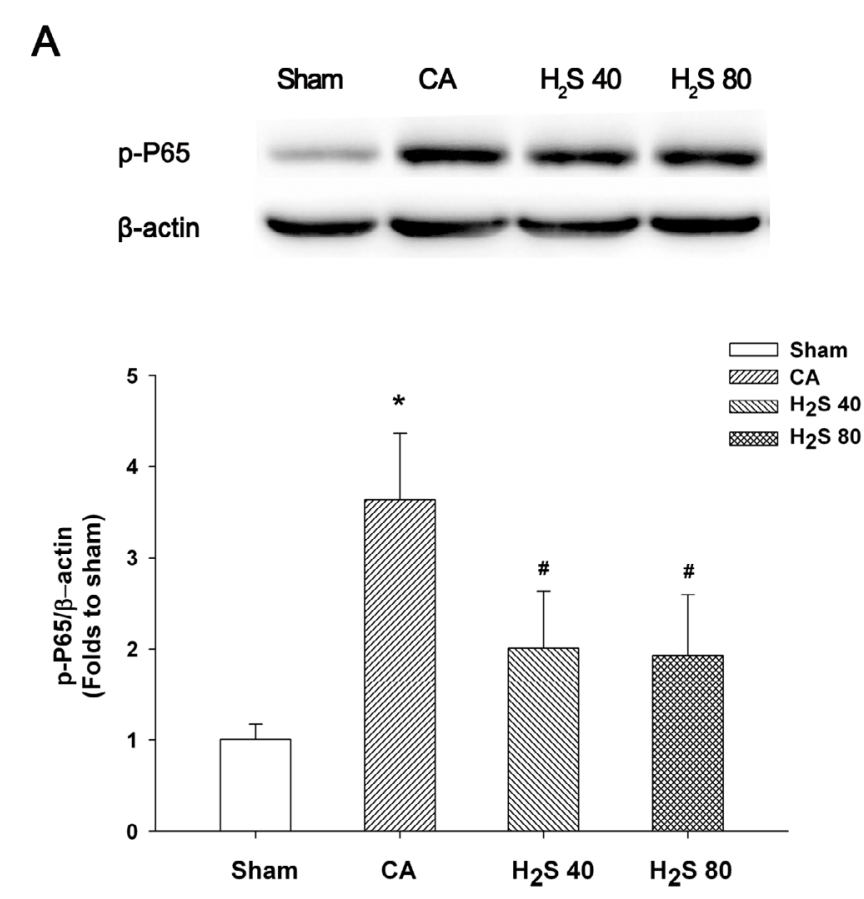

B
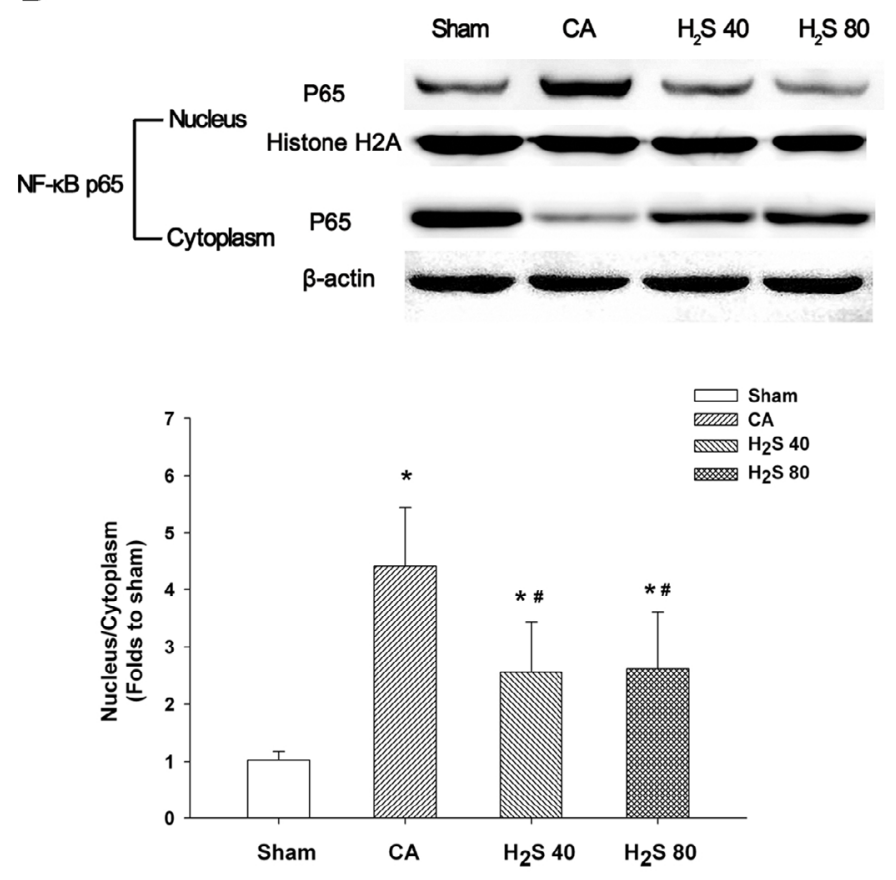

with the CA group, the levels of IL- $1 \beta$ were significant decreased in the $\mathrm{H}_{2} \mathrm{~S} 40$ group (29.17 $\pm 4.40 \mathrm{pg} / \mathrm{mg}, P<0.05)$ and $\mathrm{H}_{2} \mathrm{~S} 80$ group $(22.30 \pm 7.74 \mathrm{pg} / \mathrm{mg}, P<0.05)$. There was no significant difference between $\mathrm{H}_{2} \mathrm{~S} 40$ group and $\mathrm{H}_{2} \mathrm{~S} 80$ group $(P>0.05)$ (Fig. 5A).

CA/CPR leaded to significant increases of IL-6 levels in the CA group $(54.65 \pm 10.68$ $\mathrm{pg} / \mathrm{mg}), \mathrm{H}_{2} \mathrm{~S} 40$ group $(35.60 \pm 8.27 \mathrm{pg} / \mathrm{mg})$ and $\mathrm{H}_{2} \mathrm{~S} 80$ group $(32.03 \pm 2.12 \mathrm{pg} / \mathrm{mg}$ ) when compared with the sham group $(16.99 \pm 4.19 \mathrm{pg} / \mathrm{mg}$, both $P<0.05)$. But inhalation of $\mathrm{H}_{2} \mathrm{~S}$ leaded to a significant decrease in IL-6 levels in the $\mathrm{H}_{2} \mathrm{~S} 40$ group and $\mathrm{H}_{2} \mathrm{~S} 80$ group when compared with the CA group (both $P<0.05$ ) (Fig. 5A). 
Fig. 7. Effects of $\mathrm{H}_{2} \mathrm{~S}$ on the expression of iNOS and ICAM-1 protein in brain tissue following CA/CPR in Sham, CA, $\mathrm{H}_{2} \mathrm{~S} 40$ and $\mathrm{H}_{2} \mathrm{~S} 80$ groups after CA/CPR. Representative western blots for iNOS, ICAM-A and $\beta$-actin are shown above the bars. Sham = sham group; $\mathrm{CA}=$ cardiac arrest group; $\mathrm{H}_{2} \mathrm{~S} 40=\mathrm{H}_{2} \mathrm{~S} 40$ group; $\mathrm{H}_{2} \mathrm{~S} 80=\mathrm{H}_{2} \mathrm{~S} 80$ group. ${ }^{*} P<0.05$ vs. Sham group, ${ }^{\#} P<0.05$ vs. CA group.

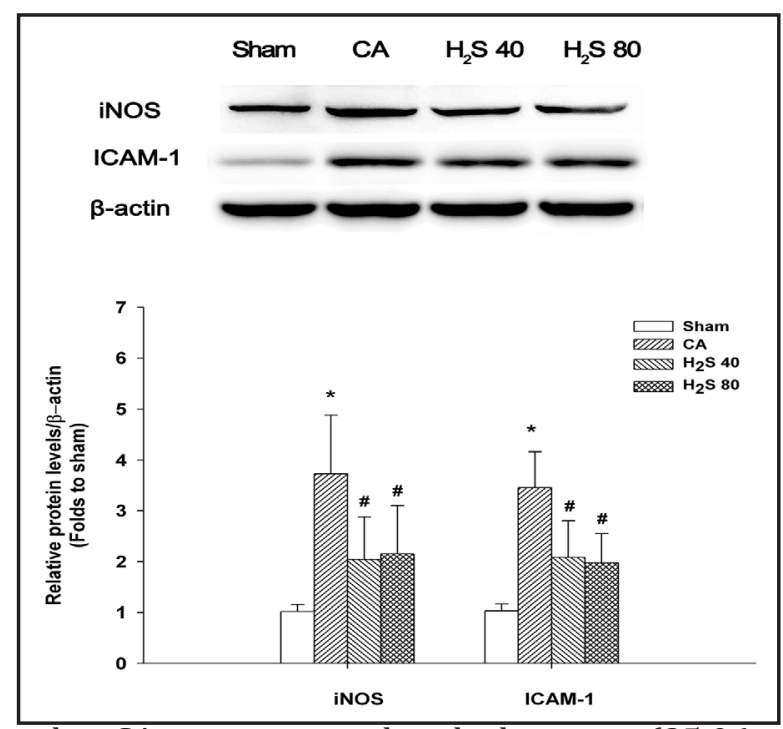

TNF- $\alpha$ levels were significantly elevated in CA rats compared with sham rats $25.06 \pm$ $2.47 \mathrm{pg} / \mathrm{mg}$ vs. $10.11 \pm 1.80 \mathrm{pg} / \mathrm{mg}, P<0.05)$ at $24 \mathrm{~h}$ after ROSC, but these increases were significantly inhibited by $40 \mathrm{ppm} \mathrm{H}_{2} \mathrm{~S}(19.73 \pm 1.60 \mathrm{pg} / \mathrm{mg}, P<0.05)$ and $80 \mathrm{ppm} \mathrm{H}_{2} \mathrm{~S}(17.64$ $\pm 2.21 \mathrm{pg} / \mathrm{mg}, P<0.05)$ treatment. However, the levels of TNF- $\alpha$ in the $\mathrm{H}_{2} \mathrm{~S} 40$ group and $\mathrm{H}_{2} \mathrm{~S}$ 80 group were not significant different $(P>0.05)$ (Fig. 5A).

Significantly increased MPO activity in brain tissue was observed in the CA group when compared with the sham group at $24 \mathrm{~h}(0.33 \pm 0.08 \mathrm{U} / \mathrm{g}$ vs. $0.09 \pm 0.05 \mathrm{U} / \mathrm{g}, P<0.05)$ after ROSC (Fig. 5B). Compared with the CA group, these increases were significantly inhibited in the $\mathrm{H}_{2} \mathrm{~S} 40$ group $(0.17 \pm 0.07, P<0.05)$ and $\mathrm{H}_{2} \mathrm{~S} 80$ group $(0.19 \pm 0.11, P<0.05)$.

\section{Inhalation of H2S ininhibits $N F-\kappa B$ activation in ischemic brain}

$\mathrm{CA} / \mathrm{CPR}$ resulted in a statistically significant increase in the expression of NF- $\kappa \mathrm{B}$ p65 phosphorylation (3.63 folds to sham, $P<0.05$, Fig. 6A) as shown in CA group. In the $\mathrm{H}_{2} \mathrm{~S}$ treated group, the phosphorylation of p65 was significantly reversed in $\mathrm{H}_{2} \mathrm{~S} 40$ group $(2.01$ folds to sham, $P<0.05$ ) and $\mathrm{H}_{2} \mathrm{~S} 80$ group (1.93 folds to sham, $P<0.05$ ).

To further examine whether $\mathrm{H}_{2} \mathrm{~S}$ regulates NF- $\mathrm{kB}$ p65 translocation to the nucleus after $\mathrm{CA} / \mathrm{CPR}$, the nucleus and cytoplasm fractions were extracted. In sham group, immunoblotting for p65 was predominately located in the cytoplasm. After CA/CPR, we observed a 4.4-fold increase in nucleus/cytoplasm ratio in CA group $(P<0.05$ vs. sham, Fig. 6B), indicating the remarkable translocation of $\mathrm{p} 65$ from cytoplasm to nucleus. Inhalation of $40 \mathrm{ppm} \mathrm{H}_{2} \mathrm{~S}(2.56$ folds to sham, $P<0.05)$ or $80 \mathrm{ppm} \mathrm{H}_{2} \mathrm{~S}(2.62$ folds to sham, $P<0.05)$ significantly prevented the nuclear translocation of NF- $\mathrm{\kappa B}$ p 65 when compared with CA group. Taken together, these data suggested that inhalation of $\mathrm{H}_{2} \mathrm{~S}$ could inhibit NF- $\kappa$ B activation/translocation induced by CA/CPR.

\section{Inhalation of $H 2 S$ inhibits $N F-\kappa B$-dependent protein expression}

$\mathrm{NF}-\kappa \mathrm{B}$ is a well-known regulator of various pro-inflammatory factors. Therefore, the pro-inflammatory mediators including iNOS and ICAM-1 in the ischemic brain tissue were tested. Immunoblotting results showed that after $24 \mathrm{~h}$ of CA/CPR, the values of iNOS elevated significantly in the CA group (3.73 folds to sham, $P<0.05$ ) when compared with sham group (Fig. 7). However, the levels of increased iNOS dropped significantly in $\mathrm{H}_{2} \mathrm{~S} 40$ group (2.05 folds to sham, $P<0.05$ ) and $\mathrm{H}_{2} \mathrm{~S} 80$ group $(2.16$ folds to sham, $P<0.05$ ) when compared with CA group. Meanwhile, $\mathrm{H}_{2} \mathrm{~S}$ also significantly decreased the expression of ICAM-1 in the $40 \mathrm{ppm}$ group (2.08 folds to sham, $P<0.0$ ) and $80 \mathrm{ppm}$ group $(1.98$ folds to sham, $P<0.05$ ) when compared with CA group (3.45 folds to sham, $P<0.05)$. However, we observed no significant difference between the $\mathrm{H}_{2} \mathrm{~S} 40$ group and $\mathrm{H}_{2} \mathrm{~S} 80$ group in iNOS and ICAM-1 (both $P>0.05)$. 


\section{Discussion}

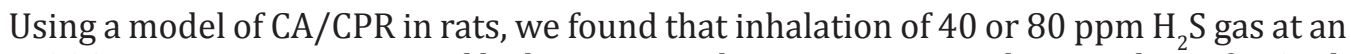
early ROSC stage was accompanied by better neurologic outcomes and survival rate for $14 \mathrm{~d}$. These improvements were associated with an inhibition of inflammation reaction as shown by IL-1 $\beta$, IL-6, TNF- $\alpha$, and MPO measurements at $24 \mathrm{~h}$ after CPR. The inhibition of NF- $\kappa B$ and pro-inflammatory cytokines iNOS and ICAM-1 is a possible mechanism for $\mathrm{H}_{2} \mathrm{~S}$ treatment.

In previous mice study, the neuroprotective effects of $\mathrm{H}_{2} \mathrm{~S}$ had been partly attributed to hypothermia [20]. However, these results had been questioned deeply in lager animals even in rats [21-23]. In our previous study with rabbit, no significant differences in rectal, cortex, and hippocampus temperature were observed after $80 \mathrm{ppm}_{2} \mathrm{~S}$ inhalation [11]. Stein and colleagues further pointed out that rats were largely insensitive to $\mathrm{H}_{2} \mathrm{~S}$-induced low body temperature unless $\mathrm{O}_{2}$ tension was decreased to $10.5 \%$ [23]. To exclude the interference of hypothermia, the pericranial temperature in this study were maintained at $37.5 \pm 0.5^{\circ} \mathrm{C}$ throughout the experiments. However, the neuroprotective effects of $\mathrm{H}_{2} \mathrm{~S}$ were also observed with better neurologic outcomes and survival rate after CA/CPR. Therefore, the neuroprotective effect of $\mathrm{H}_{2} \mathrm{~S}$ in this study was not dependent on hypothermia.

There is increasing evidence demonstrating that inflammatory processes play pivotal roles in the pathophysiology of brain damage after CA/CPR [24-27]. The inflammation is characterized by activation of the complement system, cytokines, and leukocytes. Those effects may be observed as early as $3 \mathrm{~h}$ after CA/CPR and may last for several days, as demonstrated by Adrie et al., with a description of "sepsis-like syndrome" [26]. Using 6 min of CA in rats, Teschendorf et al. demonstrated that inflammatory markers (such as TNF- $\alpha$ and ICAM-1) were significantly upregulated on the mRNA level in brain tissue as early as 6 $\mathrm{h}$ after CA [24]. The findings of the present study further confirm that IL-6, TNF- $\alpha$, and MPO activities were increased in the brain tissue of rats after CA/CPR. There was some evidence that high IL- 6 and TNF- $\alpha$ serum levels were associated with early neurological worsening and a higher mortality rate $[5,26]$. In agreement with these findings, our data suggested that the inflammation after CA/CPR might have a similar impact, because IL-1 $\beta$, IL- 6 and TNF- $\alpha$ levels were significantly elevated in the CA group with bad neurological outcome.

$\mathrm{H}_{2} \mathrm{~S}$ has recently been shown to exert several anti-inflammatory effects in different models. For instance, it had been shown that administration of $\mathrm{H}_{2} \mathrm{~S}$ donor (NaHS) would attenuate myocardial injury through inhibition of ICAM-1 expression and polymorphonuclear leukocyte accumulation [12]. In the gastrointestinal tract, $\mathrm{H}_{2} \mathrm{~S}$ had been shown to promote the resolution of mucosal inflammation to heal ulcers, while suppression of endogenous $\mathrm{H}_{2} \mathrm{~S}$ synthesis resulted in an increased granulocyte infiltration [13]. $\mathrm{H}_{2} \mathrm{~S}$ was also reported to induce neutrophil apoptosis and to suppress NSAID-induced granulocyte infiltration, as well as the expression of some leukocyte, endothelial adhesion molecules, and TNF- $\alpha$ $[14,15]$. Moreover, Yin and coauthors showed that, after global cerebral ischemia and reperfusion, exogenous $\mathrm{H}_{2} \mathrm{~S}$ attenuated pro-inflammatory markers TNF- $\alpha$ and monocyte chemoattractant protein-1 in a dose-dependent manner [28]. Additionally, recent research by Xuan and colleague revealed that exogenous NaHS reduced the over-expression in IL-1 $\beta$ and TNF- $\alpha$, as well as the extensive astrogliosis and microgliosis in the hippocampus of rat model of Alzheimer's disease [29]. All these studies suggested that $\mathrm{H}_{2} \mathrm{~S}$ played an important role in anti-inflammatory effects. Similar to these previous studies, in the present work, the pro-inflammatory cytokine IL-1 $\beta$, IL- 6 and TNF- $\alpha$ were inhibited in the $\mathrm{H}_{2} \mathrm{~S}$ group. Further, a relatively better neurological outcome was observed at the same time. The present findings, in conjunction with previously published data $[12-15,28,29]$, suggested that $\mathrm{H}_{2} \mathrm{~S}$ might improve neurological outcomes through attenuating CA/CPR-induced inflammation.

Recent studies had shown that the pathogenic role of neutrophils including accumulation in cerebral capillaries and infiltration into the brain parenchyma was induced by neuroinflammatory mediators that released from ischemic brain tissue, and MPO activity was always used as an index of neutrophil activation and infiltration [12-14]. Inhibition of neutrophil activation and infiltration into the ischemic brain was associated with an 


\section{Cellular Physiology Cell Physiol Biochem 2015;36:1527-1538 \\ \begin{tabular}{ll|l} 
and Biochemistry & $\begin{array}{l}\text { DOI: 10.1159/000430316 } \\
\text { Published online: July 06, } 2015\end{array}$ & $\begin{array}{l}\text { C 2015 S. Karger AG, Basel } \\
\text { www.karger.com/cpb }\end{array}$ \\
\hline Wei et al: H S Improves Neurological Outcome via NF-kB-Mediated Inflammation after CPR
\end{tabular}}

improving neurological outcome $[15,28]$. In this study, we found here that inhalation of 40 or $80 \mathrm{ppm} \mathrm{H}_{2} \mathrm{~S}$ markedly inhibited the increased MPO activities induced by CA/CPR, and improved neurological results were observed. It is therefore reasonable to postulate that $\mathrm{H}_{2} \mathrm{~S}$ protects against brain injury after CA/CPR through reducing neutrophils activation or infiltration.

The NF- $\kappa$ B pathway is considered to play important roles in a variety of central nervous system injury such as traumatic brain injury, transient focal ischemia and global ischemia [30]. Under normal conditions, NF-kB exists in the cytoplasm in an inactive form. Once activated, subunits of NF- $\kappa B$ translocate into the nucleus and bind to their cognate DNA binding sites to mediate transcription of various inflammatory genes or their products such as iNOS, ICAM-1, TNF- $\alpha$, IL-1 $\beta$ and IL-6 [30]. Thus, inhibitors of NF- $\kappa B$ activation may have therapeutic potential for brain protection. Transgenic mice with inactivation of astroglial $\mathrm{NF}-\kappa \mathrm{B}$ shown enhanced neuroprotection in autoimmune encephalomyelitis by suppressing central nervous system inflammation [31]. Additionally, inhibition of NF- $\kappa \mathrm{B}$ in vivo reduced astrogliosis and suppressed neuroinflammation in a transgenic mouse model of Alzheimer disease [32]. Similarly, Williams et al. demonstrated that modulation of NF- $\kappa B$ activity with MLN519 attenuated the expression of ICAM- 1 , TNF- $\alpha$, IL-1 $\beta$ and IL- 6 , and reduced neutrophil infiltration into the brain [33].

iNOS and ICAM-1 are downstream target genes of NF- $\kappa B$ [34-36]. The up-regulation of iNOS resultd in the further production of large amounts of nitric oxide, which played critical roles in controlling most inflammatory processes $[34,36]$. Previously study had shown that ICAM-1 was transcriptionally regulated by NF- $\kappa B$, and NF- $\kappa B$ p 65 transactivated the ICAM1 promoter in a $\kappa B$ site-dependent manner [37]. The up-regulation of ICAM-1 played a key role in the recruitment and extravasation of circulating leukocytes at sites of tissue injury [34-36].

In our experiment, the phosphorylation and translocation of NF- $\mathrm{B}$ p65 increased

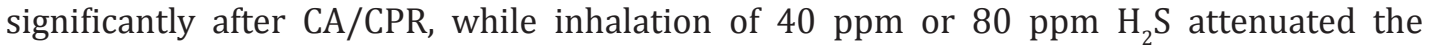
phosphorylation and translocation of NF- $\kappa \mathrm{B}$, reflecting the effective blockage of CA/CPRinduced NF- $\kappa \mathrm{B}$ activation. Further, our data suggested that inhalation of $\mathrm{H}_{2} \mathrm{~S}$ efficiently attenuated the levels of iNOS, ICAM-1, TNF- $\alpha$, IL-1 $\beta$ and IL- 6 . Taken all these together, we demonstrated that the neuroprotection offered by $\mathrm{H}_{2} \mathrm{~S}$ was at least partially attributed to its anti-inflammatory properties and this neuroprotection was more likely associated with downregulation of NF- $\kappa \mathrm{B}$ and the downstream proinflammatory signaling pathway.

In this study, $40 \mathrm{ppm}$ and $80 \mathrm{ppm}_{2} \mathrm{~S}$ were choose to explore the dose-dependent effects of $\mathrm{H}_{2} \mathrm{~S}$ on CA/CPR because these doses were safe and low concentrations for rat [38], and were widely used in previous animal studies and no obvious toxic effects including the histological and behavioral outcome were observed [11,21,39].

Last, but not least, we must point out that the dose-dependent protective effect of $\mathrm{H}_{2} \mathrm{~S}$ was not demonstrated in this study. Inhalation of $40 \mathrm{ppm}$ or $80 \mathrm{ppm}_{2} \mathrm{~S}$ produced the same effects in nearly all the parameters measured. Hence we infer that there might be a maximal effects by inhalation $\mathrm{H}_{2} \mathrm{~S}$. Future studies on different concentration and duration of $\mathrm{H}_{2} \mathrm{~S}$ are warranted to determine the optimum concentration and therapeutic schedule of $\mathrm{H}_{2} \mathrm{~S}$. In addition, the translational implication of $\mathrm{H}_{2} \mathrm{~S}$ in the human clinical setting is uncertain and needs to be investigated.

\section{Conclusion}

In summary, the findings presented here provide evidence suggesting that inhalation of $\mathrm{H}_{2} \mathrm{~S}$ protects against brain injury after $\mathrm{CA} / \mathrm{CPR}$. The mechanisms underlying protective effects of $\mathrm{H}_{2} \mathrm{~S}$ are associated with the inhibition of CA/CPR-induced inflammation reactions by reducing the levels of IL- $1 \beta$, IL- 6 and TNF- $\alpha$, and concomitantly inhibiting the activation and infiltration of neutrophils. The beneficial effects of $\mathrm{H}_{2} \mathrm{~S}$ might be mediated by downregulation of NF- $\mathrm{KB}$ and the downstream proinflammatory signaling pathway. 


\section{Cellular Physiology Cell Physiol Biochem 2015;36:1527-1538 \begin{tabular}{ll|l} 
and Biochemistry & $\begin{array}{l}\text { DOI: 10.1159/000430316 } \\
\text { Published online: July 06, } 2015\end{array}$ & $\begin{array}{l}\text { C 2015 S. Karger AG, Basel } \\
\text { www.karger.com/cpb }\end{array}$ \\
\hline
\end{tabular}

\section{Disclosure Statement}

The authors declare no conflict of interest.

\section{Acknowledgements}

This study was supported by grants from the Educational Commission of Heilongjiang Province, China (1251G041) \& the National Natural Science Foundation of China (81372026, 81000822 ). The funders had no role in study design, data collection and analysis, decision to publish, or preparation of the manuscript.

\section{References}

1 Young GB: Clinical practice. Neurologic prognosis after cardiac arrest. N Engl J Med 2009;361:605-611.

2 Callans DJ: Out-of-hospital cardiac arrest--the solution is shocking. N Engl J Med 2004;351:632-634.

3 Albert CM, Chae CU, Grodstein F, Rose LM, Rexrode KM, Ruskin JN, Stampfer MJ, Manson JE: Prospective study of sudden cardiac death among women in the United States. Circulation 2003;107:2096-2101.

4 Amantea D, Nappi G, Bernardi G, Bagetta G, Corasaniti MT: Post-ischemic brain damage: pathophysiology and role of inflammatory mediators. FEBS J 2009;276:13-26.

5 Fries M, Stoppe C, Brücken D, Rossaint R, Kuhlen R: Influence of mild therapeutic hypothermia on the inflammatory response after successful resuscitation from cardiac arrest. J Crit Care 2009;24:453-457.

6 Kim JY, Kawabori M, Yenari MA: Innate inflammatory responses in stroke: mechanisms and potential therapeutic targets. Curr Med Chem 2014;21:2076-2097.

7 Wang R: Physiological implications of hydrogen sulfide: a whiff exploration that blossomed. Physiol Rev 2012;92:791-896.

8 Avanzato D, Merlino A, Porrera S, Wang R, Munaron L, Mancardi D: Role of calcium channels in the protective effect of hydrogen sulfide in rat cardiomyoblasts. Cell Physiol Biochem 2014; 33: 1205-1214.

9 Kida K, Minamishima S, Wang H, Ren J, Yigitkanli K, Nozari A, Mandeville JB, Liu PK, Liu CH, Ichinose F: Sodium sulfide prevents water diffusion abnormality in the brain and improves long term outcome after cardiac arrest in mice. Resuscitation 2012;83:1292-1297.

10 Pan H, Xie X, Chen D, Zhang J, Zhou Y, Yang G: Protective and biogenesis effects of sodium hydrosulfide on brain mitochondria after cardiac arrest and resuscitation. Eur J Pharmacol 2014;741:74-82.

11 Wei X, Duan L, Bai L, Tian M, Li W, Zhang B: Effects of exogenous hydrogen sulfide on brain metabolism and early neurological function in rabbits after cardiac arrest. Intensive Care Med 2012;38:1877-1885.

12 Sivarajah A, Collino M, Yasin M, Benetti E, Gallicchio M, Mazzon E, Cuzzocrea S, Fantozzi R, Thiemermann C: Anti-apoptotic and anti-inflammatory effects of hydrogen sulfide in a rat model of regional myocardial I/R. Shock 2009;31:267-274.

13 Wallace JL, Ferraz JG, Muscara MN. Hydrogen sulfide: an endogenous mediator of resolution of inflammation and injury. Antioxid Redox Signal 2012;17:58-67.

14 Zanardo RC, Brancaleone V, Distrutti E, Fiorucci S, Cirino G, Wallace JL: Hydrogen sulfide is an endogenous modulator of leukocyte-mediated inflammation. FASEB J 2006;20:2118-2120.

15 Fiorucci S, Antonelli E, Distrutti E, Rizzo G, Mencarelli A, Orlandi S, Zanardo R, Renga B, Di Sante M, Morelli A, Cirino G, Wallace JL: Inhibition of hydrogen sulfide generation contributes to gastric injury caused by anti-inflammatory nonsteroidal drugs. Gastroenterology 2005;129:1210-1224.

16 Guo R, Wu K, Chen J, Mo L, Hua X, Zheng D, Chen P, Chen G, Xu W, Feng J: Exogenous hydrogen sulfide protects against doxorubicin-induced inflammation and cytotoxicity by inhibiting p38MAPK/NFkB pathway in H9c2 cardiac cells. Cell Physiol Biochem 2013;32:1668-1680.

17 Janata A, Drabek T, Magnet IA, Stezoski JP, Janesko-Feldman K, Popp E, Garman RH, Tisherman SA, Kochanek PM: Extracorporeal versus conventional cardiopulmonary resuscitation after ventricular fibrillation cardiac arrest in rats: a feasibility trial. Crit Care Med 2013;41:e211-e222.

18 Albertsmeier M, Teschendorf P, Popp E, Galmbacher R, Vogel P, Böttiger BW: Evaluation of a tape removal test to assess neurological deficit after cardiac arrest in rats. Resuscitation 2007;74:552-558.

19 Paxinos G, Watson C: The Rat Brain in Stereotaxic Coordinates, ed 5. Amsterdam, Elsevier Academic Press, 2005. 


\section{Cellular Physiology Cell Physiol Biochem 2015;36:1527-1538

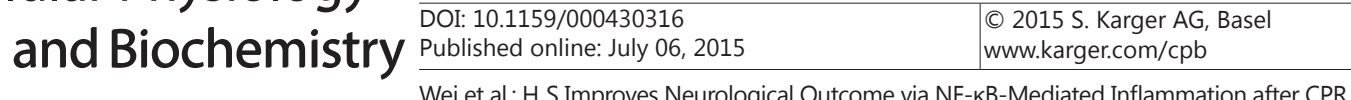

20 Blackstone E, Morrison M, Roth MB: H2S induces a suspended animation-like state in mice. Science 2005;308:518.

21 Li J, Zhang G, Cai S, Redington AN: Effect of inhaled hydrogen sulfide on metabolic responses in anesthetized, paralyzed, and mechanically ventilated piglets. Pediatr Crit Care Med 2008;9:110-112.

22 Haouzi P, Notet V, Chenuel B, Chalon B, Sponne I, Ogier V, Bihain B: H2S induced hypometabolism in mice is missing in sedated sheep. Respir Physiol Neurobiol 2008;160:109-115.

23 Stein A, Mao Z, Morrison JP, Fanucchi MV, Postlethwait EM, Patel RP, Kraus DW, Doeller JE, Bailey SM: Metabolic and cardiac signaling effects of inhaled hydrogen sulfide and low oxygen in male rats. J Appl Physiol 2012;112:1659-1669.

24 Teschendorf P, Albertsmeier M, Vogel P, Padosch SA, Spöhr F, Kirschfink M, Schwaninger M, Böttiger BW, Popp E: Neurological outcome and inflammation after cardiac arrest--effects of protein C in rats. Resuscitation 2008;79:316-324.

25 Böttiger BW, Motsch J, Braun V, Martin E, Kirschfink M: Marked activation of complement and leukocytes and an increase in the concentrations of soluble endothelial adhesion molecules during cardiopulmonary resuscitation and early reperfusion after cardiac arrest in humans. Crit Care Med 2002;30:2473-2480.

26 Adrie C, Adib-Conquy M, Laurent I, Monchi M, Vinsonneau C, Fitting C, Fraisse F, Dinh-Xuan AT, Carli P, Spaulding C, Dhainaut JF, Cavaillon JM: Successful cardiopulmonary resuscitation after cardiac arrest as a "sepsis-like" syndrome. Circulation 2002;106:562-568.

27 Schneider A, Albertsmeier M, Böttiger BW, Teschendorf P: Post-resuscitation syndrome. Role of inflammation after cardiac arrest. Anaesthesist 2012;61:424-436.

28 Yin J, Tu C, Zhao J, Ou D, Chen G, Liu Y, Xiao X: Exogenous hydrogen sulfide protects against global cerebral ischemia/reperfusion injury via its anti-oxidative, anti-inflammatory and anti-apoptotic effects in rats. Brain Res 2013;1491:188-196.

29 Xuan A, Long D, Li J, Ji W, Zhang M, Hong L, Liu J: Hydrogen sulfide attenuates spatial memory impairment and hippocampal neuroinflammation in $\beta$-amyloid rat model of Alzheimer's disease. J Neuroinflammation 2012;9: 202.

30 Tak PP, Firestein GS: NF-kappaB: a key role in inflammatory diseases. J Clin Invest 2001;107:7-11.

31 Brambilla R, Persaud T, Hu X, Karmally S, Shestopalov VI, Dvoriantchikova G, Ivanov D, Nathanson L, Barnum SR, Bethea JR: Transgenic inhibition of astroglial NF-kappa B improves functional outcome in experimental autoimmune encephalomyelitis by suppressing chronic central nervous system inflammation. J Immunol 2009;182:2628-2640.

32 Zhang X, Luhrs KJ, Ryff KA, Malik WT, Driscoll MJ, Culver B: Suppression of nuclear factor kappa B ameliorates astrogliosis but not amyloid burden in APPswe/PS1dE9 mice. Neuroscience 2009; 161: 53-58.

33 Williams AJ, Dave JR, Tortella FC: Neuroprotection with the proteasome inhibitor MLN519 in focal ischemic brain injury: relation to nuclear factor kappaB (NF-kappaB), inflammatory gene expression, and leukocyte infiltration. Neurochem Int 2006;49:106-112.

34 Raza SS, Khan MM, Ahmad A, Ashafaq M, Islam F, Wagner AP, Safhi MM, Islam F: Neuroprotective effect of naringenin is mediated through suppression of NF- $\mathrm{\kappa B}$ signaling pathway in experimental stroke. Neuroscience 2013;230:157-171.

35 Guan T, Liu Q, Qian Y, Yang H, Kong J, Kou J, Yu B: Ruscogenin reduces cerebral ischemic injury via NF-кB-mediated inflammatory pathway in the mouse model of experimental stroke. Eur J Pharmacol 2013;714:303-311.

36 He W, Chen W, Zhou Y, Tian Y, Liao F: Xanthotoxol exerts neuroprotective effects via suppression of the inflammatory response in a rat model of focal cerebral ischemia. Cell Mol Neurobiol 2013; 33: 715-722.

37 Ledebur HC, Parks TP: Transcriptional regulation of the intercellular adhesion molecule-1 gene by inflammatory cytokines in human endothelial cells. Essential roles of a variant NF-kappa B site and p65 homodimers. J Biol Chem 1995;270:933-943.

38 Struve MF, Brisbois JN, James RA, Marshall MW, Dorman DC: Neurotoxicological effects associated with short-term exposure of Sprague-Dawley rats to hydrogen sulfide. Neurotoxicology 2001;22:375-385.

39 Volpato GP, Searles R, Yu B, Scherrer-Crosbie M, Bloch KD, Ichinose F, Zapol WM: Inhaled hydrogen sulfide: a rapidly reversible inhibitor of cardiac and metabolic function in the mouse. Anesthesiology 2008;108:659-668. 